\title{
RESEARCH
}

Open Access

\section{Effects of reflexology on premenstrual syndrome: a systematic review and meta- analysis}

Marzieh Hasanpour, Mohammad Mehdi Mohammadi ${ }^{*}$ and Habib Shareinia

\begin{abstract}
Background: Premenstrual syndrome (PMS) refers to a set of somatic and psychological symptoms that occur cyclically in the luteal phase of a menstrual cycle. There is no report of final result of reflexology on PMS. Therefore, the present study aimed to determine the effect of reflexology on PMS through a systematic review and metaanalysis study.

Method: The present study was a systematic review and meta-analysis that was conducted by searching in 8 electronic databases including PubMed, EMBASE, Cochrane Library, Web of Science, ProQuest, Scopus, Google Scholar, and SID until December 28, 2018. In this regard, interventional studies, which examined the impact of reflexology on women with premenstrual syndrome, were included. These studies were published during 1993 to 2018. The Cochrane Collaboration's Risk of Bias Tool was used to assess the quality of studies. Meta-analysis was performed by the help of CMA 2 software.
\end{abstract}

Results: Nine out of 407 studies finally remained after screening, and quantitative and quantitative analyses were performed on them. The total number of research samples was 475 . The mean treatment time with reflexology was 40.55 min per session that was performed in 6 to 10 sessions of treatment in $66.67 \%$ of studies. According to the meta-analysis and based on the random effects model, the reflexology could decrease the severity of PMS in the intervention group compared to the control group ( $\mathrm{SMD}=-2.717,95 \% \mathrm{Cl}:-3.722$ to -1.712 ). Metaregression results indicated that the duration of intervention sessions $(\beta=-0.1124,95 \% \mathrm{Cl}-0.142$ to $-0.084, p<$ $0.001)$ had a significant impact on the severity of PMS. Reflexology could also significantly affect somatic (SMD $=-$ $1.142,95 \% \mathrm{Cl}:-1.481$ to -0.803$)$ and psychological ( $\mathrm{SMD}=-1.380,95 \% \mathrm{Cl}:-2.082$ to -0.677$)$ symptoms arising from PMS.

Conclusion: In general, results of the present study indicated that the reflexology could relieve PMS symptoms, so that overall scores, somatic and psychological symptoms of PMS decreased by applying the reflexology intervention. Furthermore, an increase in the length of reflexology time in each session increased its efficiency. Reflexology can be used as an effective intervention in a patient care program by nurses and its efficiency can be enhanced by increasing intervention time in each reflexology treatment session.

Keywords: Premenstrual syndrome (PMS), Reflexology, Systematic review, Massage, Meta-analysis

\footnotetext{
* Correspondence: mehdi20.mohamadi@gmail.com

School of Nursing and Midwifery, Tehran University of Medical Sciences,

Tehran, Iran
}

(c) The Author(s). 2019 Open Access This article is distributed under the terms of the Creative Commons Attribution 4.0 International License (http://creativecommons.org/licenses/by/4.0/), which permits unrestricted use, distribution, and reproduction in any medium, provided you give appropriate credit to the original author(s) and the source, provide a link to the Creative Commons license, and indicate if changes were made. The Creative Commons Public Domain Dedication waiver (http://creativecommons.org/publicdomain/zero/1.0/) applies to the data made available in this article, unless otherwise stated. 


\section{Background}

Premenstrual syndrome (PMS) refers to a set of somatic and psychological symptoms that occur cyclically in the luteal phase of a menstrual cycle [1]. PMS was first introduced as a diagnostic concept by Raymond Greene and Katharina Dalton in 1953 [2]. The global prevalence of this syndrome is $47.8 \%$ in the world. Some countries have reported the prevalence of PMS as follows: Spain: 73\%, Switzerland: 19\%, China: 21\%, Brazil: 60\%, and India: $67 \%$ [3]. According to the evidence, this prevalence is $98 \%$ in Iran [4].

Clinical symptoms of PMS can be divided into two categories: somatic and psychological. The symptoms occur cyclically just before menstruation and disappear when menstrual bleeding starts. Major somatic symptoms include swelling, breast tenderness, headache, increased appetite and palpitations; and psychological symptoms include depression, irritability, fatigue, aggression, suicidal tendency, and social isolation [5].

PMS can affect women's quality of life, so that most of these women have somatic problems (dizziness, headache, nausea, palpitation, sweating, pain, weakness, and lethargy) and psychological problems (anxiety, anger, depression, irritability, isolation, stress, and impatience) [6].

The exact cause of this syndrome is unknown, and symptoms are reported such as changes at estrogen and progesterone levels, central changes in catecholamines, response to prostaglandins, reduction of dopamine and central serotonin levels what are now more taken into consideration. There is no effective single treatment, which is universally accepted, for this syndrome [7].

PMS can be treated by pharmacological and nonpharmacological treatments. The pharmacological treatment include diuretics, gonadotropin-releasing hormone $(\mathrm{GnRH})$ agonist, and non-steroidal anti-inflammatory drugs (NSAIDs) and the main pharmacological treatments include combined oral contraceptives (COCs) and selective serotonin reuptake inhibitors (SSRIs) [8]. The prescribed drugs for this purpose are associated with undesirable effects such as fatigue, headache, irritability, depression and gastrointestinal bleeding [9, 10]. Nonpharmacological methods, which are called complementary therapies, such as the reflexology are more secure and have fewer complications than pharmaceutical methods $[11,12]$.

Reflexology is a systematic function based on which points of hands, legs, or ears are placed under some pressure. It is based on the fact that the stimulation of reflex points on palms, legs, and ears matches each part of the body including muscle, nerve, gland and bone. In other words, reflex points indicate functions of various organs of the body. When reflex points are stimulated, body cells affect the health of a body organ, which is associated with that reflex point, by creating a reflex impact [13]. The reflexology therapy mechanism can be studied based on its main origin, so that Traditional Chinese Medicine (TCM) expresses that under this mechanism, the stimulation of reflex points leads to the restoration, reconstruction, and balance of vital Qi energy, thereby treating diseases [14].. In general, the precise mechanism of reflexology operation is still unknown, but there are different theories on the efficiency of reflexology. According to the regional theory, there are certain reflexes in hands, ears, and legs and they are associated with glands, organs, and parts of the body by energy channels or meridians. It is believed that these energy channels are blocked during illness or imbalance in the body. Opening these blocked paths, reflexology massage leads to a free flow of energy in the body and thus the body regain its health and balance. Based on the theory of neural message, the reflexology inhibits the transmission of pain by controlling the transmission of afferent nerve signals and closure of nerve valve in the posterior branch of the spinal cord $[14,15]$.

There is no final result of reflexology's impact on PMS. In other words, the scientific community needs to create a clear insight into the effect of reflexology on PMS. A systematic review and meta-analysis study can summarize the results of previous studies and provide a clear result in this regard. Given that there was no systematic review and meta-analysis study on this field, the present study aimed to determine the impact of reflexology on PMS in women.

\section{Methods}

\section{Search strategy}

The present study was conducted in accordance with the Preferred Reporting Items for Systematic Reviews and Meta-analyses (PRISMA) statement [16]. In this regard, 8 electronic databases including PubMed, EMBASE, Cochrane Library, Web of Science, ProQuest, Scopus, Google Scholar, and SID were searched until December 28, 2018. The applied keywords in the search included Premenstrual Syndrome; Premenstrual Complaints; Reflexology; Zone Therapy; Massage; Menstruation; Menstrual, and Premenstrual Symptoms. In addition, references of all studies were manually searched and reviewed in order to ensure a comprehensive search. All references were made by two authors, who independently searched, and the results were then merged. The full search strategy was attached to the research (Additional file 1).

\section{Inclusion and exclusion criteria}

Studies, which had the following criteria, were eligible:

1. Type of design: RCT (Randomized Controlled Trial) or Quasi-experimental designs 
2. Population: Participants with PMS

3. Intervetion group: Reflexology as intervention

4. Outcome: Overall scores, somatic or psychological symptoms of PMS are measured and reported.

5. Control group: Placebo or non-treatment are considered in this group.

Studies, which used reflexology in combination with other interventions (e.g. relaxation), were excluded from the research. Furthermore, studies without a control or comparison group were excluded.

\section{Study selection method}

A strategy, which was proportional to each database, was used to search studies. The manual search was also performed to find thesis, dissertation and conference proceedings. Duplicated studies were deleted by EndNote software, and what remained was under the initial screening. In this regard, the eligibility of studies was independently examined by two authors; and any disagreement between two investigators was resolved by the third party. At the first stage, titles and abstracts of studies were first assesed for the initial screening; and each author independently selected studies with the inclusion criteria, and then remaining studies were selected through a full-text study. Finally, a quantitative and qualitative analysis was performed on remaining studies.

\section{Quality of studies}

The Cochrane Collaboration's Risk of Bias Tool was utilized to assess the quality of studies [17]. The risk of bias was rated using a Low/High/Unclear Grading Scale in studies (Table 1). It should be noted that two authors independently studied the quality of studies.

One study used a random number table for the Random Sequence Generation [18]. Two studies used software for random allocation [11, 12]. Four studies did not clearly report the Random Sequence Generation [20, 22-24] and two other studies considered High Risk of Bias [19, 21].

Seven studies did not clearly report the allocation concealment [11, 12, 18, 20, 22-24], and two studies considered High Risk of Bias [19, 21].

Blinding was evaluated separately for outcome assessors and patients. In three studies, patients did not know which of intervention or control groups they were allocated $[11,12,18]$. There was no possibility of judgment in other studies due to poor reporting [19-24]. About blinding outcome assessors, one research directly reported that blinding was only performed on samples and data analyzers; and outcome assessors were not blind [12]. Outcome assessor blinding was not clearly reported in other studies [11, 18-24]. Table 1 presents other examined dimensions.

\section{Data extraction method}

Two authors independently extracted data. In this regard, a data extraction form was used including the author's name (year of publication), country, design study, sample size, type of intervention, number of sessions, and duration of each session, research group, age range (or mean age) of measured outcomes and measurement tools.

\section{Statistical analysis method}

In the present study, the meta-analysis was done using Comprehensive Meta-Analysis software (CMA, Version 2.0, New England, NJ, USA). The standardized difference was calculated with 95\% confidence interval as the effect size. In the study, a random effects model was used; and the heterogeneity of studies was analyzed using $\mathrm{I}^{2}$ value. The analysis sub-group and metaregression were used to further investigate the

Table 1 Risk of Bias of Included Studies*

\begin{tabular}{|c|c|c|c|c|c|c|}
\hline \multirow[t]{2}{*}{ (Citation) Study (Year) } & \multicolumn{2}{|l|}{ Selection Bias } & \multirow{2}{*}{$\begin{array}{l}\text { Patient } \\
\text { Blinding }\end{array}$} & \multirow{2}{*}{$\begin{array}{l}\text { Assessor } \\
\text { Blinding }\end{array}$} & \multirow{2}{*}{$\begin{array}{l}\text { Incomplete } \\
\text { Outcome } \\
\text { Data }\end{array}$} & \multirow{2}{*}{$\begin{array}{l}\text { Selective } \\
\text { Outcome } \\
\text { Reporting }\end{array}$} \\
\hline & Random Sequence Generation & Allocation Concealment & & & & \\
\hline [18] Oleson (1993) & L & U & L & U & L & $L$ \\
\hline [19] Kim (2002) & $\mathrm{H}$ & $\mathrm{H}$ & U & $U$ & L & L \\
\hline [20] Kim (2004) & U & $U$ & U & U & $U$ & L \\
\hline [21] Lee (2011) & $\mathrm{H}$ & $\mathrm{H}$ & U & U & L & L \\
\hline [11] Abdollahi Fard (2013) & L & U & L & $U$ & L & L \\
\hline [22] Baghdassarians (2015) & U & U & U & U & $U$ & $U$ \\
\hline [23] Nalini (2015) & $U$ & $U$ & U & $U$ & U & L \\
\hline [24] Prema (2017) & U & $U$ & U & $U$ & $U$ & U \\
\hline [12] Shafaie (2018) & L & U & L & $\mathrm{H}$ & L & L \\
\hline
\end{tabular}

*Domains of Quality Assessment Based on the Cochrane Tools for Assessing Risk of Bias 
heterogeneity source; and included studies were allocated to sub-groups in terms of country, studied age group, study design, type of comparison group, and type of reflexology. In order to perform the metaregression, duration of intervention sessions and the study publication year were considered as moderating variables. In order to calculate the Pre-Post Correlation, the Standard Deviation of Changes ( $\left.\mathrm{SD}_{\text {change }}\right)$ was extracted based on a study by Lee et al. [21], and then, the Pre-Post Correlation was estimated at 0.803 using the following formula, and finally generalized to other studies.

$$
\mathrm{r}=\left(\mathrm{SD}_{\text {pre }} \wedge 2+\mathrm{SD}_{\text {post }} \wedge 2-\mathrm{SD}_{\text {change }} \wedge 2\right) /\left(2 * \mathrm{SD}_{\text {pre }} *\right.
$$
$\left.\mathrm{SD}_{\text {post }}\right)$

Publication Bias was examined using the Funnel Plot, and a test by Begg and Egger; and the trim and fill method was then used to measure the Adjusted Effect Size if there was a publication bias. Sensitivity analysis was used to investigate the robustness of results.

\section{Results}

\section{Study selection}

The applied search strategy in databases detected 307 studies; and 10 other studies were then added to them after manual search of references and complementary search in theses and conferences. After removal of duplicated studies $(n=75)$, the research screening began with 242 studies; hence, 207 studies were excluded from the study by evaluating their titles and abstracts. The full text of 35 papers was then studied, and 26 studies were excluded due to the lack of compliance of intervention type with the inclusion criteria and the lack of control group. Finally, 9 remained studies were investigated by qualitative and quantitative analyses (Fig. 1).

\section{Study characteristics}

Nine studies (6 RCT and 3 Quasi- experimental studies published during 1993 to 2018) were selected for the present study. The total number of study samples was 475 . Studies were conducted in the United States [18], North

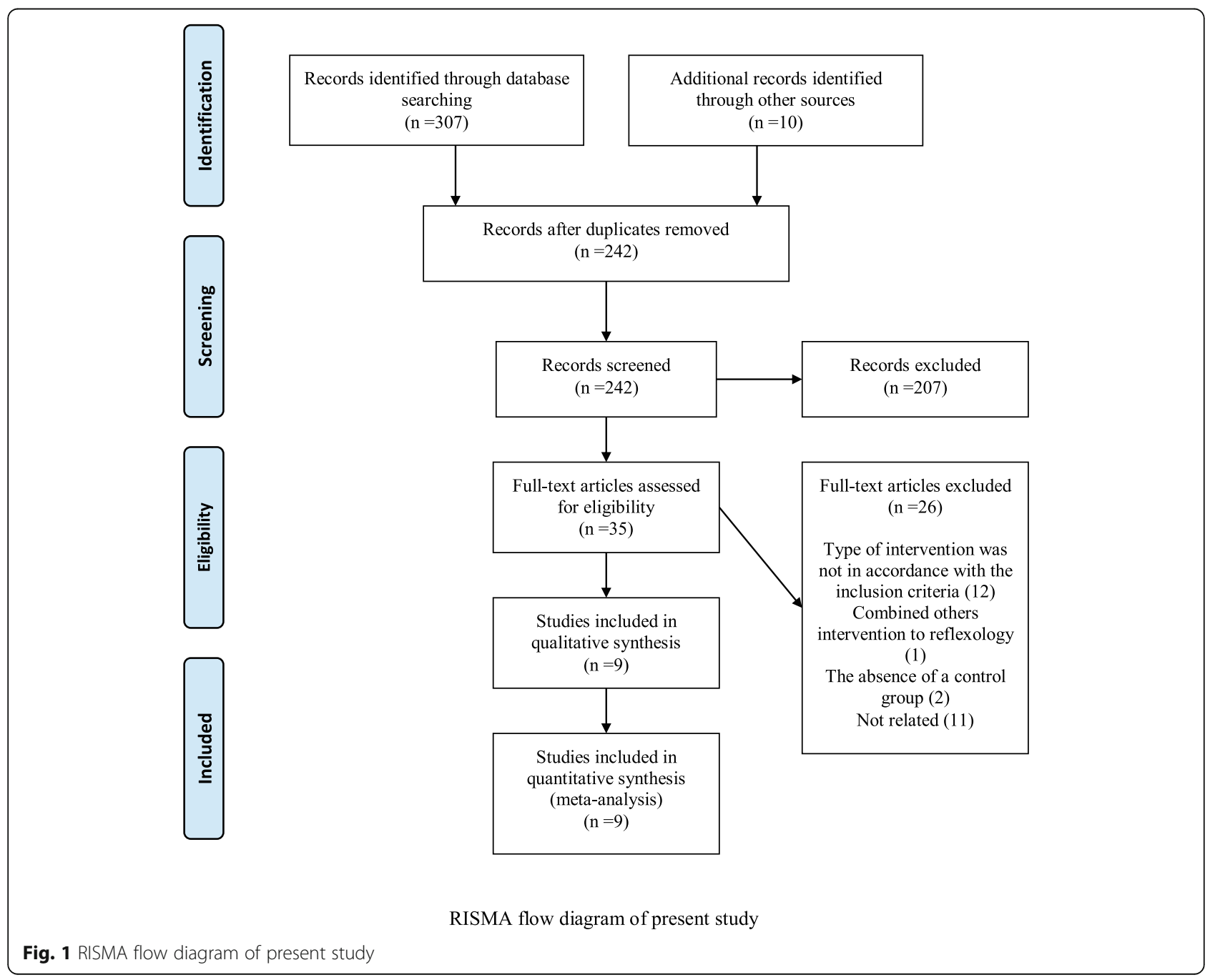


Korea [19-21], India [23, 24], and Iran [11, 12, 22]. A total of 3 studies were published in English [18, 23, 24, and], 3 in Persian [11, 12, 22] and 3 in Korean [19-21]. Six studies were randomized clinical trials $[11,12,18,20,22,24]$ and three ones were semi experimental $[19,21,23]$. The average treatment time with reflexology was 40.55 min per session that was performed in 6 to 10 treatment sessions in $66.67 \%$ of studies. Table 2 presents other details of included studies.

\section{Effect of reflexology on overall score of PMS}

All nine selected studies examined the impact of reflexology on overall score of PMS [11, 12, 18-24]. According to the meta-analysis and based on random effects model, the reflexology could be decreasing the severity of PMS in the intervention group compared to the control group $(\mathrm{SMD}=-2.717,95 \% \mathrm{CI}:-3.722$ to -1.712 ); however, Shafaie et al. (SMD $=-0.333,95 \%$ CI: -0.726 to 0.060 ) did not reported any significant result (Fig. 2). Heterogeneity of studies was also significant $\left(\mathrm{I}^{2}=\right.$ 94.41\%, $P<0.001)$.

\section{Examination of heterogeneity source}

The subgroup analysis and meta-regression were used to investigate source of heterogeneity. Subgroup analysis was performed based on research year, country, type of research design, type of comparison group, type of reflexology, and age group of research participants; however, results of the subgroup analysis indicated that the source of heterogeneity was not resulted from the above factors. In order to perform the metaregression, duration of intervention sessions and the research publication years were considered as moderating variables. Meta-regression results indicated that

Table 2 Characteristics of included studies

\begin{tabular}{|c|c|c|c|c|c|c|c|c|}
\hline $\begin{array}{l}\text { Author } \\
\text { (Publication } \\
\text { year) }\end{array}$ & Country & $\begin{array}{l}\text { Design } \\
\text { of Study }\end{array}$ & $\begin{array}{l}\text { Sample } \\
\text { Size } \\
\text { /Group }\end{array}$ & $\begin{array}{l}\text { Type of } \\
\text { Intervention }\end{array}$ & $\begin{array}{l}\text { Intervention } \\
\text { Time } \\
\text { Schedule }\end{array}$ & $\begin{array}{l}\text { Population (Mean } \\
\text { or age range) }\end{array}$ & Outcomes Measures & Instrument \\
\hline $\begin{array}{l}\text { Oleson } \\
\text { (1993) }\end{array}$ & USA & $\mathrm{RCT}$ & $\begin{array}{l}35 \\
E G: 18 \\
C G: 17\end{array}$ & $\begin{array}{l}\text { EG: Foot, hand } \\
\text { and ear } \\
\text { reflexology; CG: } \\
\text { Placebo } \\
\text { reflexology }\end{array}$ & $30 \mathrm{~min}$ & $\begin{array}{l}\text { Females with } \\
\text { Premenstrual } \\
\text { symptoms (Mean } \\
\text { age: EG:37.2; CG: } \\
\text { 32.7) }\end{array}$ & $\begin{array}{l}\text { Total PMS; Somatic } \\
\text { symbtoms; Psychological } \\
\text { symbtoms }\end{array}$ & $\begin{array}{l}\text { PMS scale (made } \\
\text { by researcher) }\end{array}$ \\
\hline Kim (2002) & $\begin{array}{l}\text { South } \\
\text { Korea }\end{array}$ & $\begin{array}{l}\text { Quasi } \\
\text { expermental } \\
\text { desin }\end{array}$ & $\begin{array}{l}40 \\
E G: 20 \\
C G: 20\end{array}$ & $\begin{array}{l}\text { EG: Foot } \\
\text { reflexology; CG: } \\
\text { no treatment }\end{array}$ & $60 \mathrm{~min}$ & $\begin{array}{l}\text { Female college } \\
\text { student (range: } \\
21-33 \text { years) }\end{array}$ & $\begin{array}{l}\text { Total PMS and } \\
\text { dysmenorrhea }\end{array}$ & $\begin{array}{l}\text { Keele VAS and } \\
\text { opening records }\end{array}$ \\
\hline Kim (2004) & $\begin{array}{l}\text { South } \\
\text { Korea }\end{array}$ & $\mathrm{RCT}$ & $\begin{array}{l}48 \\
E G: 24 \\
C G: 24\end{array}$ & $\begin{array}{l}\text { EG: Self foot } \\
\text { reflexology; CG: } \\
\text { no treatment }\end{array}$ & $35 \mathrm{~min}$ & $\begin{array}{l}\text { High school girls } \\
\text { (range: U) }\end{array}$ & $\begin{array}{l}\text { Total PMS; Behavioral } \\
\text { symbtoms; Psychological } \\
\text { symbtoms; Dysmenorrhea }\end{array}$ & MDQ; VAS \\
\hline Lee (2011) & $\begin{array}{l}\text { South } \\
\text { Korea }\end{array}$ & $\begin{array}{l}\text { Quasi } \\
\text { expermental } \\
\text { desin }\end{array}$ & $\begin{array}{l}61 \\
E G: 37 \\
C G: 24\end{array}$ & $\begin{array}{l}\text { EG: Aroma-foot- } \\
\text { reflexology; CG: } \\
\text { no treatment }\end{array}$ & $60 \min$ & $\begin{array}{l}\text { Female college } \\
\text { student (Mean } \\
\text { age: EG:19.3; } \\
\text { CG19.4) }\end{array}$ & $\begin{array}{l}\text { Total PMS and } \\
\text { dysmenorrhea; Lower } \\
\text { abdominalskin temperature }\end{array}$ & $\begin{array}{l}\text { PMS scale (made } \\
\text { by researcher); } \\
\text { VAS; Portable } \\
\text { digital skin } \\
\text { thermometer }\end{array}$ \\
\hline $\begin{array}{l}\text { Abdollahi } \\
\text { Fard (2013) }\end{array}$ & Iran & $\begin{array}{l}\text { Single blind } \\
\text { RCT }\end{array}$ & $\begin{array}{l}90 \\
E G: 45 \\
C G: 45\end{array}$ & $\begin{array}{l}\text { EG: Foot } \\
\text { reflexology; CG: } \\
\text { Placebo } \\
\text { reflexology }\end{array}$ & $30 \mathrm{~min}$ & $\begin{array}{l}\text { Female college } \\
\text { student (Mean } \\
\text { age: EG:20.8; CG: } \\
\text { 20.5) }\end{array}$ & $\begin{array}{l}\text { Total PMS; Somatic } \\
\text { symbtoms; Psychological } \\
\text { symbtoms }\end{array}$ & Daily record scale \\
\hline $\begin{array}{l}\text { Baghdassari } \\
(2015)\end{array}$ & Iran & $\mathrm{RCT}$ & $\begin{array}{l}40 \\
E G: 20 \\
C G: 20\end{array}$ & $\begin{array}{l}\text { EG: Foot } \\
\text { reflexology; CG: } \\
\text { no treatment }\end{array}$ & $60 \mathrm{~min}$ & $\begin{array}{l}\text { Females with } \\
\text { Premenstrual } \\
\text { symptoms } \\
\text { (Range: } 31-45 \text { ) }\end{array}$ & Total PMS & PMS scale \\
\hline Nalini (2015) & India & $\begin{array}{l}\text { Quasi } \\
\text { experimental }\end{array}$ & $\begin{array}{l}30 \\
E G: 15 \\
C G: 15\end{array}$ & $\begin{array}{l}\text { EG: Foot, hand } \\
\text { reflexology; CG: } \\
\text { no treatment }\end{array}$ & $40 \mathrm{~min}$ & $\begin{array}{l}\text { Female college } \\
\text { student (Range: } \\
\text { 17-20) }\end{array}$ & $\begin{array}{l}\text { Total PMS; Somatic } \\
\text { symbtoms; Psychological } \\
\text { symbtoms; Emotional } \\
\text { symptoms; Physiological } \\
\text { symptoms }\end{array}$ & PMS scale \\
\hline $\begin{array}{l}\text { Prema } \\
(2017)\end{array}$ & India & $\mathrm{RCT}$ & $\begin{array}{l}30 \\
E G: 15 \\
C G: 15\end{array}$ & $\begin{array}{l}\text { EG: Foot } \\
\text { reflexology; CG: } \\
\text { no treatment }\end{array}$ & $20 \mathrm{~min}$ & $\begin{array}{l}\text { Adolescent girls } \\
\text { (Mean age: EG:U; } \\
\text { CG:U) }\end{array}$ & $\begin{array}{l}\text { Total PMS; Psychological } \\
\text { symbtoms }\end{array}$ & VAS \\
\hline $\begin{array}{l}\text { Shafaie } \\
\text { (2018) }\end{array}$ & Iran & $\begin{array}{l}\text { Double blind } \\
\text { RCT }\end{array}$ & $\begin{array}{l}101 \\
E G: 52 \\
C G: 49\end{array}$ & $\begin{array}{l}\text { EG: Foot } \\
\text { reflexology; CG: } \\
\text { Placebo } \\
\text { reflexology }\end{array}$ & $30 \mathrm{~min}$ & $\begin{array}{l}\text { Female college } \\
\text { student (Mean } \\
\text { age: EG:22.3; CG: } \\
21.46)\end{array}$ & $\begin{array}{l}\text { Total PMS; Somatic } \\
\text { symbtoms; Behavioral } \\
\text { symptoms: Psychological } \\
\text { symbtoms }\end{array}$ & Daily record scale \\
\hline
\end{tabular}




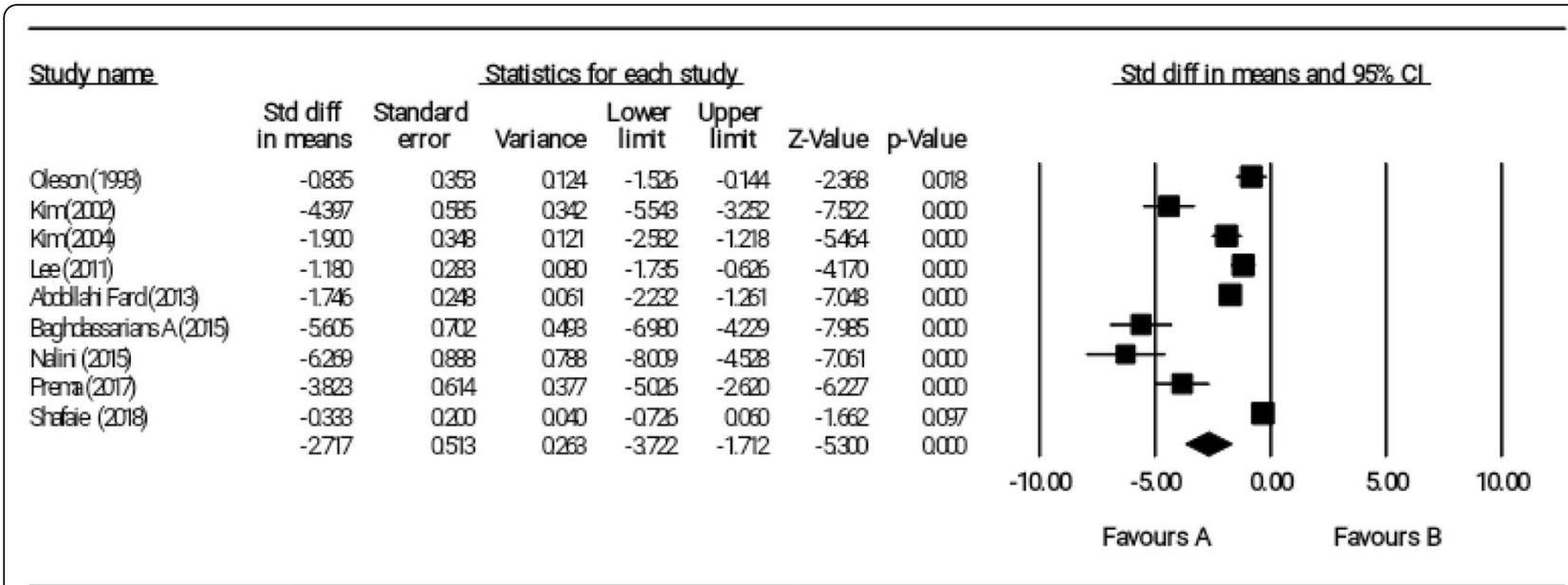

S.bto $\Delta$ nalusic

Fig. 2 Effect of reflexology on overall score of PMS

duration of intervention sessions $(\beta=-0.1124,95 \% \mathrm{CI}$ -0.142 to $-0.084, p<0.001$ ) had a significant impact on severity of PMS (Fig. 3); however, publication year did not report any significant impact $(\beta=0.022,95 \%$ CI -0.007 to $-0.051, p=0.129$ ).

\section{Publication Bias}

The Funnel Plot visually showed the probability of publication bias (Fig. 4), and then the bias was examined based on tests by Begg and Egger; and the publication bias was reported in both tests (Begg's test, $P=0.013$; Egger's test, $P=0.001$ ).

Therefore, the trim and fill method was used; accordingly, 1 study was allocated and the effect size was 2.365 that was changed by 0.335 compared to the observed effect size (-2.718), and in generally had no effect on significance of effect size.

\section{Sensitivity analysis}

The robustness of the primary results from 9 studies was supported by the sensitivity analysis; and an estimation of robustness of overall effect size was obtained by removing any study from the meta-analysis. In other words, the sensitivity analysis indicated that the exclusion of results of each study from the general analysis did not have any significant effect on overall results (Fig. 5).

Effect of reflexology on somatic symptoms of PMS Four studies investigated somatic symptoms of PMS as outcomes of study [11, 12, 18, 23]. These studies

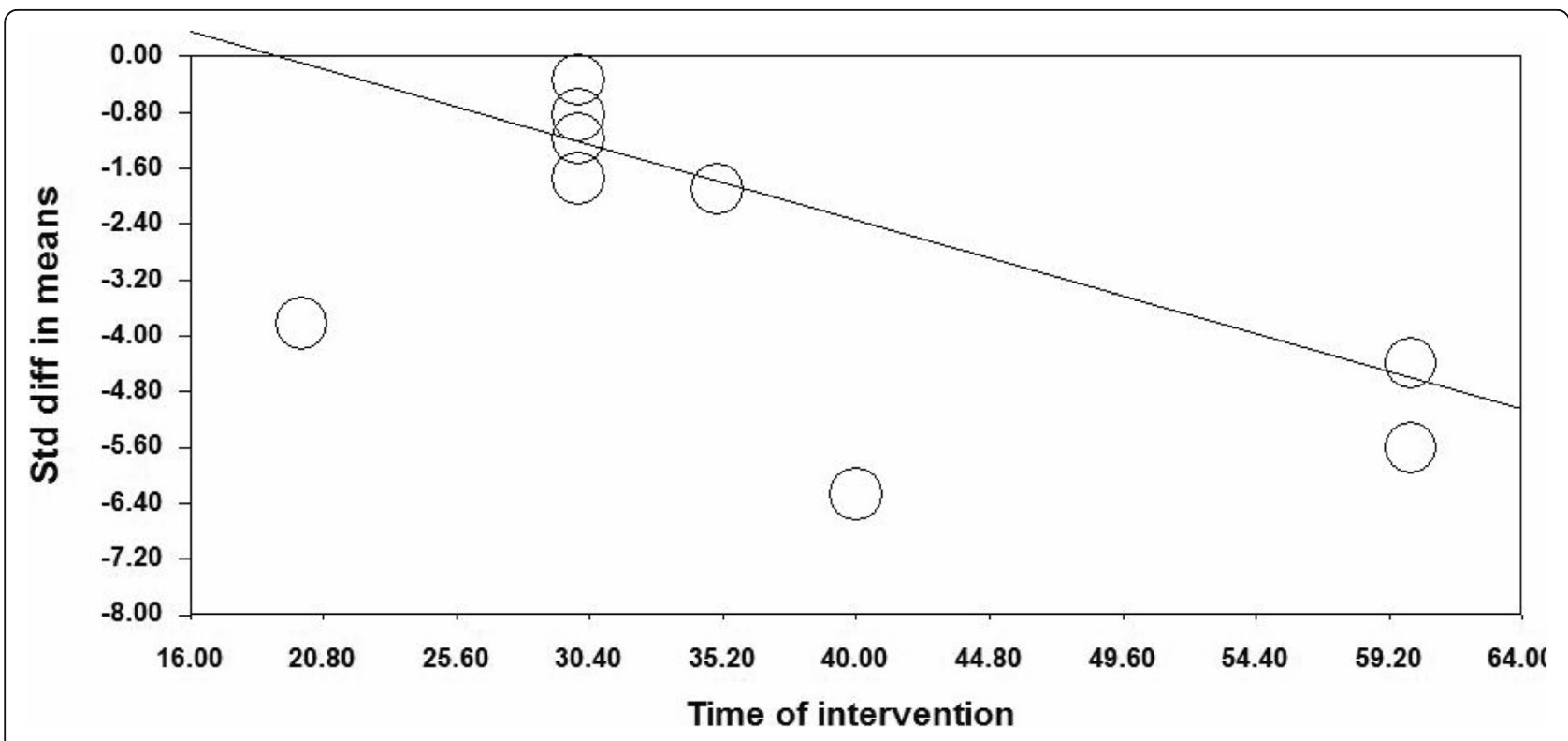

Fig. 3 Meta-regression of intervention duration on SMD in the studies investigating the effect of reflexology on total score of PMS 


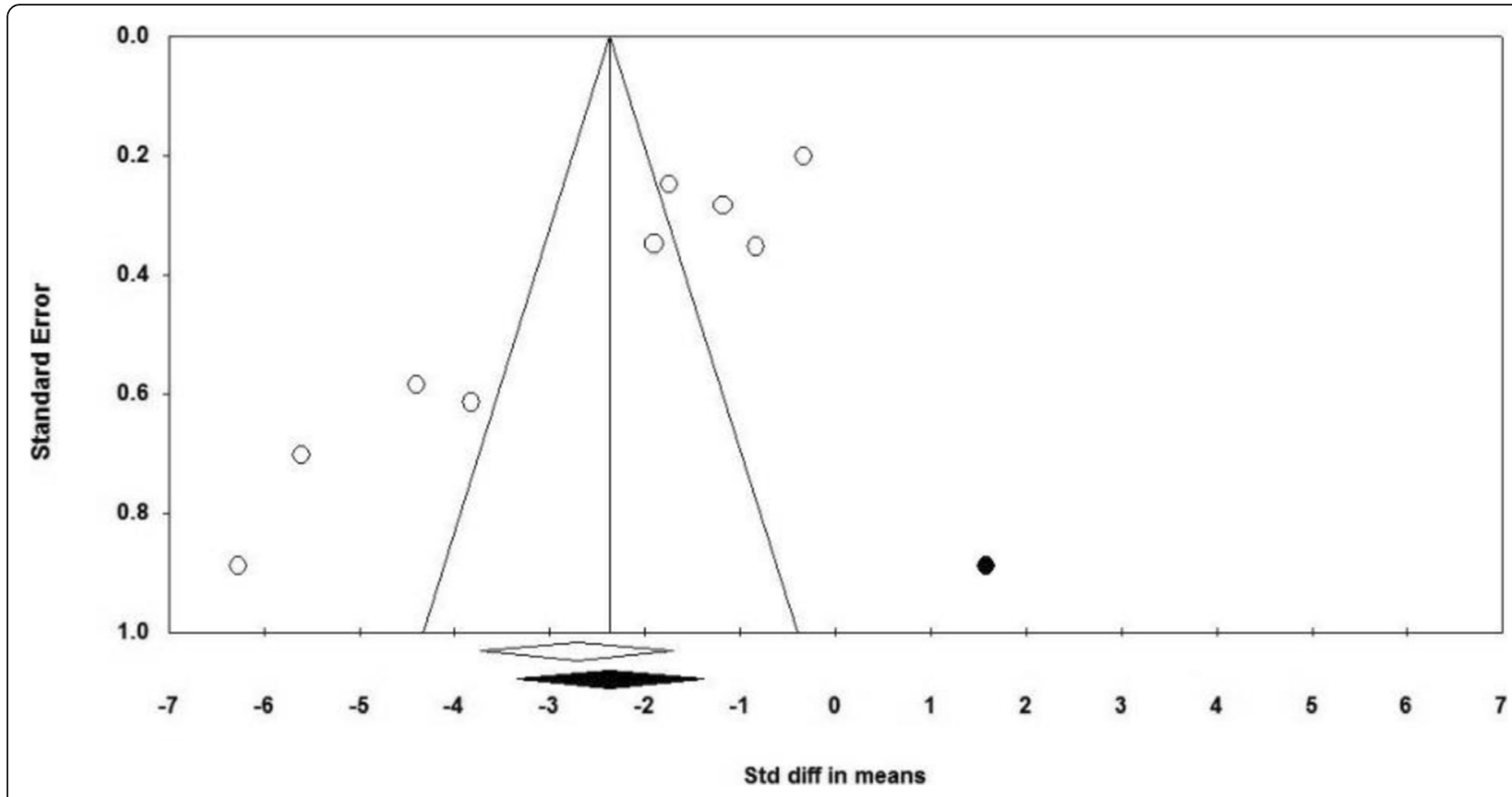

Fig. 4 Funnel plot for publication bias in the studies investigating the effect of reflexology on total score of PMS

included a total of 256 samples. The age range of participants was mostly from 17 to 38 years. The duration of each session of reflexology treatment was 32.5 min on average in papers.

Results of the meta-analysis indicated that the reflexology could significantly affect somatic symptoms of PMS based on the random effects model. (SMD $=-1.142$, 95\% CI: -1.481 to -0.803 ); (Fig. 6). Furthermore, no significant heterogeneity was reported $\left(\mathrm{I}^{2}=32.94 \%, P=0215\right)$.

\section{Publication Bias}

The funnel plot visually showed that there was no publication bias (Fig. 7). However, Egger and Begg tests also indicated that there was no publication bias (Begg's test, $P=0.497$; Egger's test, $P=0.704$ ).

\section{Sensitivity analysis}

The sensitivity analysis indicated that the exclusion of any included study in the meta-analysis would not change overall effect size (Fig. 8).

Effect of reflexology on psychological symptoms of PMS Six studies investigated psychological symptoms of PMS as an outcome $[11,12,18,20,23,24]$; so that, they measured psychological symptoms of PMS in addition to examining the impact of reflexology on overall score of PMS. The studies included a total of

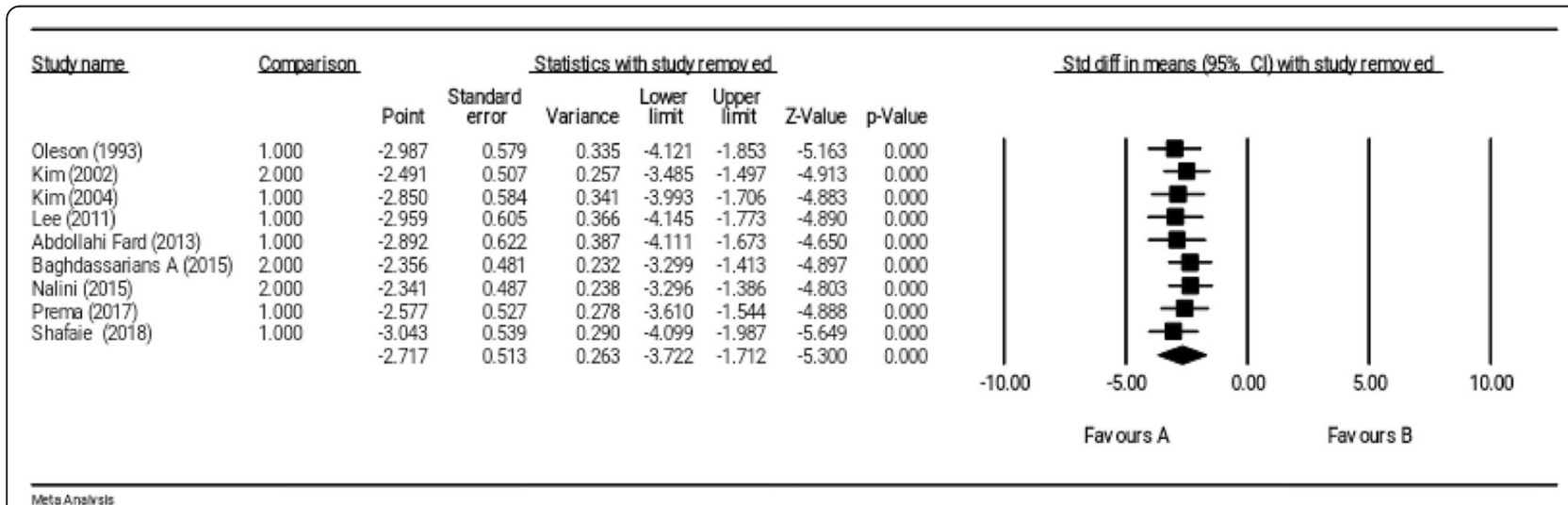

Fig. 5 Sensitivity analysis for studies investigating the effect of reflexology on total score of PMS 


\begin{tabular}{|c|c|c|c|c|c|c|c|c|c|c|c|c|}
\hline \multirow[t]{2}{*}{ Study name } & \multicolumn{8}{|c|}{ Statistics for each study } & \multicolumn{4}{|c|}{ Std diff in means and $95 \% \mathrm{Cl}$} \\
\hline & $\begin{array}{l}\text { Std diff } \\
\text { in means }\end{array}$ & $\begin{array}{l}\text { Standard } \\
\text { error }\end{array}$ & Variance & $\begin{array}{l}\text { Lower } \\
\text { limit }\end{array}$ & $\begin{array}{l}\text { Upper } \\
\text { limit }\end{array}$ & Z-Value & $\mathrm{p}$-Value & & & & & \\
\hline Oleson(1998) & -0994 & 0338 & 0128 & -1696 & -0291 & $-2 \pi / 2$ & 0006 & & & & & \\
\hline Abddlai Fad(2013) & -1.468 & 0238 & 0066 & -1.933 & -1.002 & -6179 & 0000 & & & & & \\
\hline Prena (2017) & $-13 / 36$ & 0.406 & 0165 & -2172 & -0.580 & -3338 & 0001 & & & - & & \\
\hline \multirow[t]{4}{*}{ Shafae (2018) } & -0840 & 0208 & 0,043 & -1.248 & -0433 & -4047 & 000 & & & & & \\
\hline & -1.14 & 0173 & QCBO & -1.481 & -0808 & -6608 & 000 & & & & & \\
\hline & & & & & & & & -10.00 & -5.00 & 0.00 & 500 & 1000 \\
\hline & & & & & & & & & Favours & & Favours $\mathrm{B}$ & \\
\hline
\end{tabular}

Fig. 6 Effect of reflexology on somatic symptoms of PMS

334 participants in the age group of 17 to 38 years. The mean intervention time was 30.84 per session in the studies.

According to meta-analysis result and based on the random effects model, the reflexology could significantly decrease psychological symptoms of PMS in the intervention group compared with the control group $(\mathrm{SMD}=-1.380,95 \% \mathrm{CI}:-2.082$ to -0.677$)$; however, a study $(\mathrm{SMD}=-0.494,95 \% \mathrm{CI}:-1.220$ to 0.233$)$ by Prema et al. did not report any significant result (Fig. 9). The results indicated that the heterogeneity was significant $\left(\mathrm{I}^{2}=87.05 \%, P<0.001\right)$.

\section{Heterogeneity source}

It seems that duration of intervention is the source of heterogeneity in different studies as the meta-regression results indicate a significant effect of duration of intervention on psychological symptoms of PMS $(\beta=-0.119$, $95 \%$ CI -0.175 to $-0.065, p<0.001$ ) (Fig. 10).

\section{Publication Bias}

Funnel plot and Begg and Egger test did not report any publication bias (Fig. 11). (Begg's test, $P=0.189$; Egger's test, $P=0.287)$.

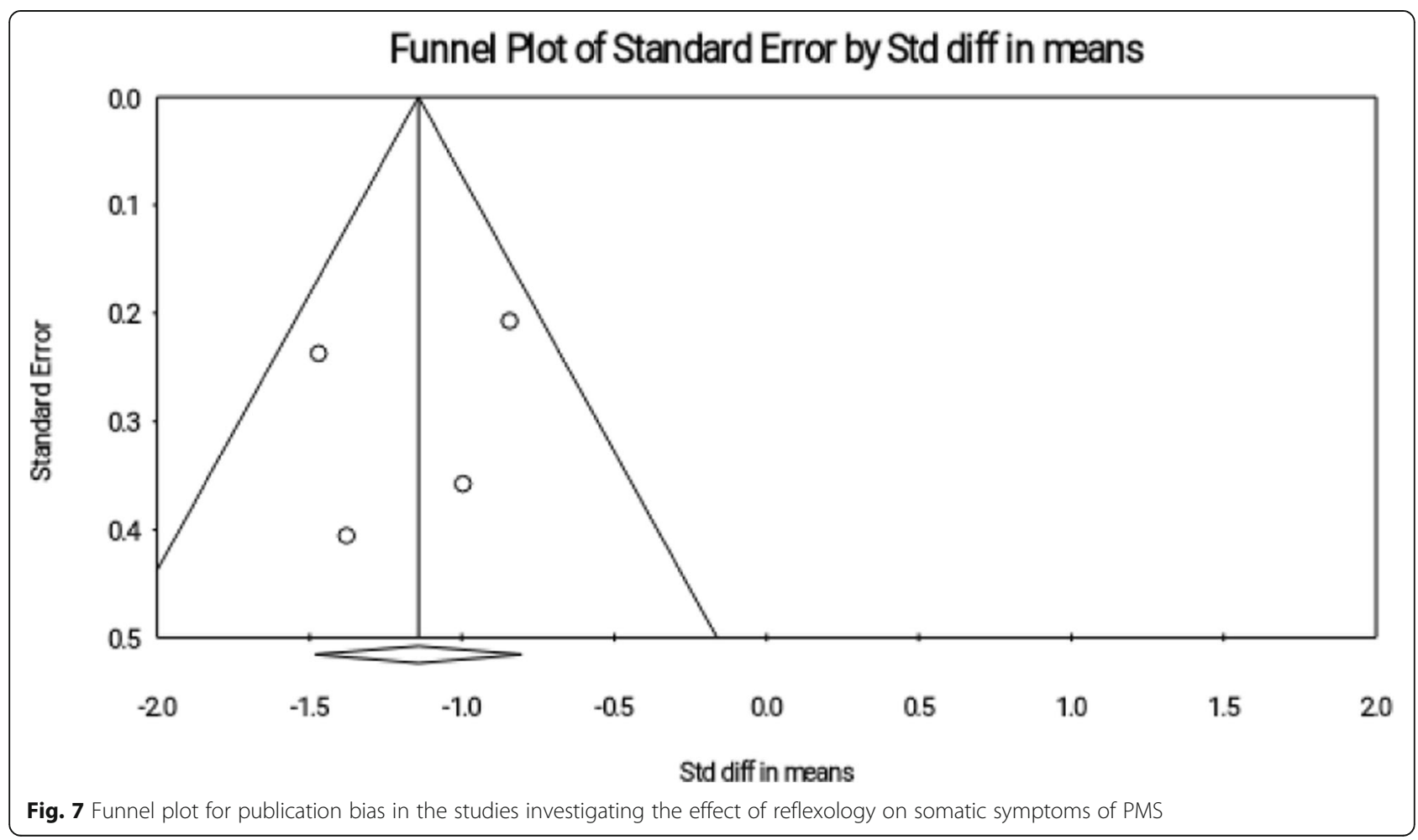




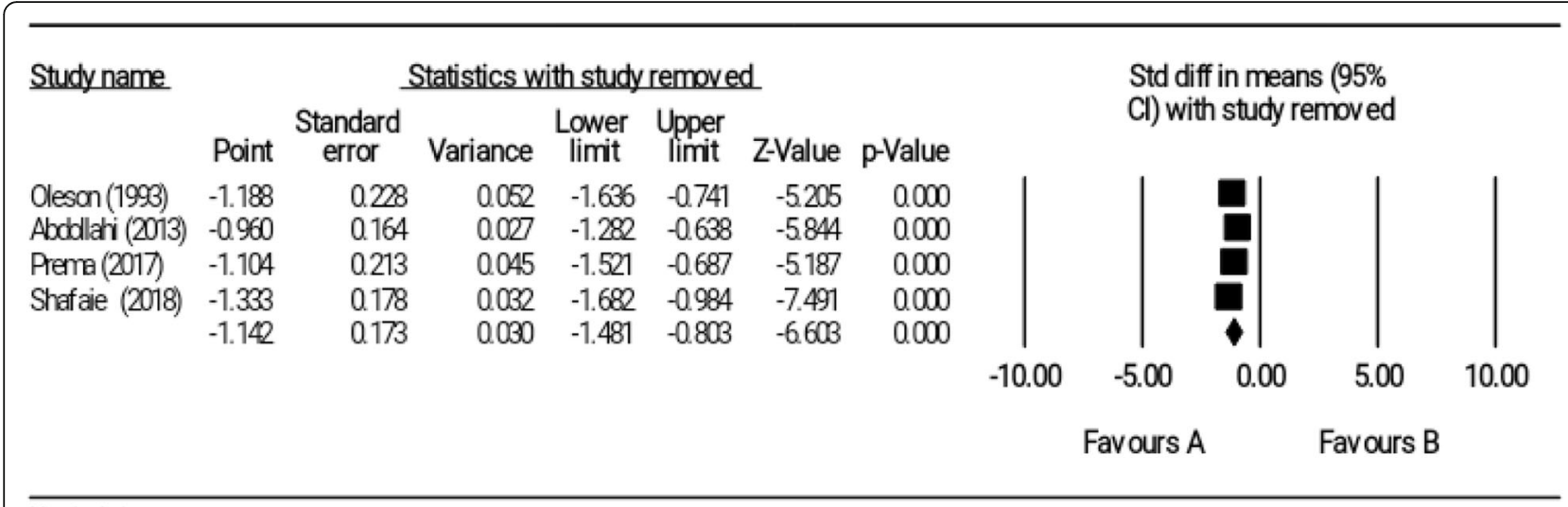

Meta Analysis

Fig. 8 Sensitivity analysis for studies investigating the effect of reflexology on somatic symptoms of PMS

\section{Sensitivity test}

Results of the sensitivity test indicated that the exclusion of each study did not affect the significance of overall effect size (Fig. 12).

\section{Discussion}

\section{Summary of evidence}

The present systematic review and meta-analysis study indicated that the reflexology as an intervention could decrease the severity of PMS symptoms in women. In this regard, we analyzed 9 studies that measured the impact of reflexology on the overall score of PMS. Metaanalysis results for overall score of PMS indicated that the reflexology could effectively relieve overall symptoms of PMS; however, effect sizes of various studies were heterogeneous. The duration of reflexology in each intervention session could explain the heterogeneity; in other words, the increased duration of using a reflexology intervention in each session enhanced its effect on the overall score of PMS. Lee and Baghdasar introduced $60 \mathrm{~min}$ as the standard time for reflexology with the greatest effect on overall score of PMS [21, 22]. It should be noted that none of 9 reported studies reported any side effect for the reflexology intervention.

The present study also indicated that the reflexology could decrease the severity of somatic symptoms of PMS. In this regard, a meta-analysis was performed on four studies with homogeneous effect sizes. There was no systematic review and meta-analysis study on the effect of reflexology on somatic symptoms of PMS; however, the effect of reflexology was investigated on some somatic symptoms in other demographic groups. In this regard, Lee et al. (2011) examined the impact of reflexology on pain, fatigue and sleep in various groups of nurses, students, elderly patients and patients. Their results indicated that the reflexology as an effective intervention could relieve fatigue and improve sleep quality, but its effect on pain was not significant in some population groups [25]. Despite the fact that the reflexology dates back to Traditional Chinese Medicine (TCM), conventional sciences have also presented its effectiveness mechanism, so that reflexology induces a sense of

\begin{tabular}{|c|c|c|c|c|c|c|c|c|c|c|c|c|}
\hline \multirow[t]{2}{*}{ Study name } & \multicolumn{7}{|c|}{ Statistics for each study } & \multicolumn{5}{|c|}{ Std diff in means and $95 \% \mathrm{Cl}$} \\
\hline & $\begin{array}{l}\text { Std diff } \\
\text { in means }\end{array}$ & $\begin{array}{l}\text { Standard } \\
\text { error }\end{array}$ & Variance & $\begin{array}{c}\text { Lower } \\
\text { limit }\end{array}$ & $\begin{array}{l}\text { Upper } \\
\text { limit }\end{array}$ & Z-Value & p-Value & & & & & \\
\hline desan(1993) & -0667 & 0347 & 0121 & -1348 & 0014 & -1918 & Q0Б & & & & & \\
\hline $\operatorname{Kirr}(20 \mathrm{OH})$ & -2162 & 0363 & 0132 & -2874 & -1.450 & -5960 & 0000 & & & & & \\
\hline Abddladi Fad (2013) & -1.710 & 0246 & 0061 & -2198 & -1.27 & -6942 & 0000 & & & & & \\
\hline Naliri (2015) & -3009 & 0535 & 0296 & $-40 / 7$ & -1.900 & -5661 & 0000 & & & & & \\
\hline Prena(X017) & -0494 & 0371 & 0137 & -1220 & 0233 & -1332 & 0183 & & & & & \\
\hline \multirow{4}{*}{ Shaje (2018) } & -0567 & 0203 & 0041 & -0964 & -0169 & -2790 & 0006 & & & & & \\
\hline & -1380 & 0359 & 0129 & -2082 & -067 & -3848 & acoo & & & & & \\
\hline & & & & & & & & -10.00 & -5.00 & 0.00 & 500 & 10.00 \\
\hline & & & & & & & & & Favours A & & Favours B & \\
\hline
\end{tabular}

Mbta Analysis

Fig. 9 Effect of reflexology on psychological symptoms of PMS 


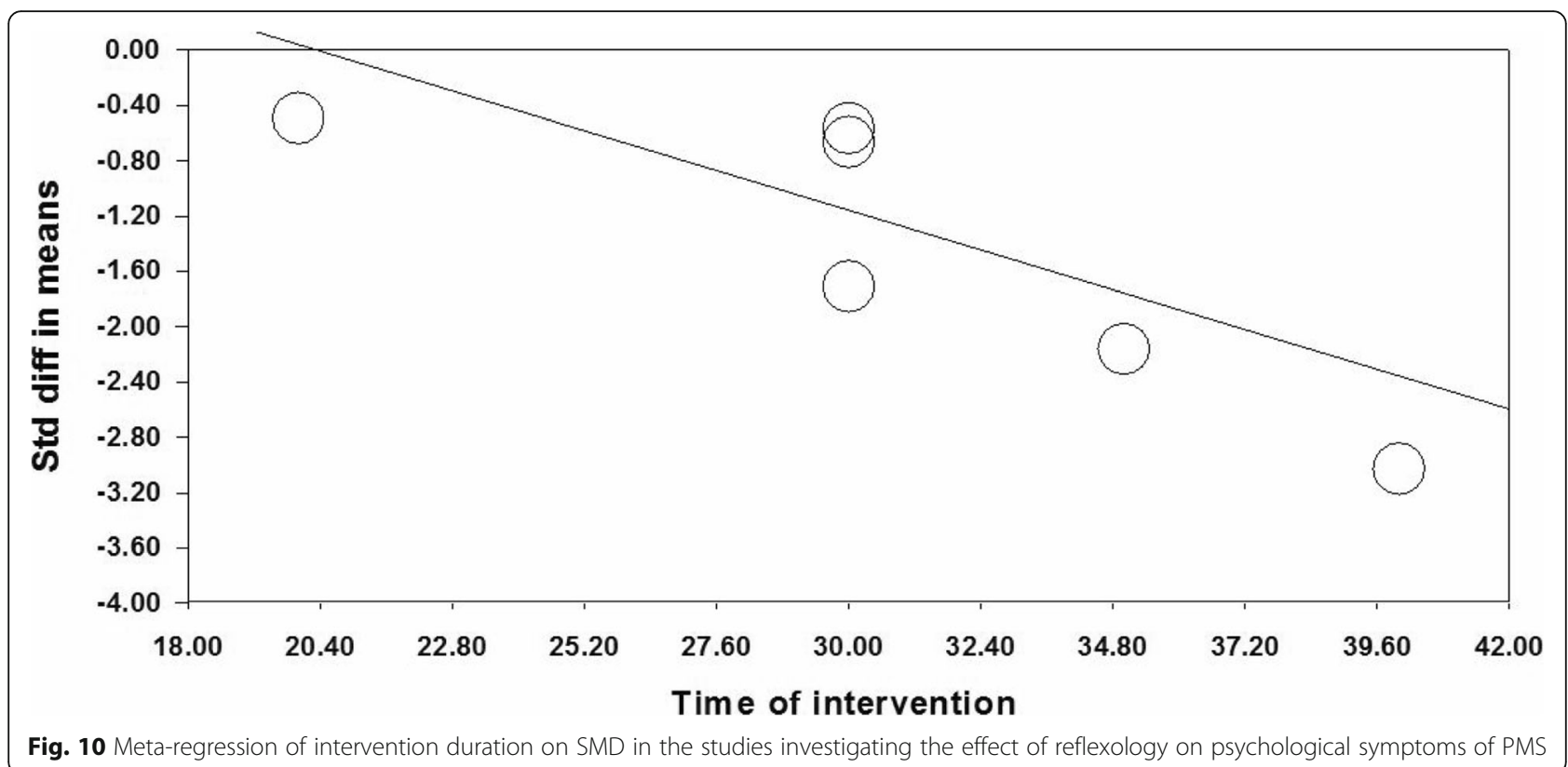

meditative relaxation that stimulates the parasympathetic system; hence, it seems that its impact on somatic symptoms of PMS is due to the improved parasympathetic functions of some body systems [14].

Other results of the present study indicated that the reflexology led to the improvement of psychological symptoms of PMS. However, effect sizes of various studies were heterogeneous. Further examination indicated that duration of each session of reflexology was the cause of this heterogeneity terms of psychological symptoms. In this regard, the increased intervention time of each session enhanced the impact of reflexology on the relief of psychological symptoms. There was no systematic review and meta-analysis study on the impact

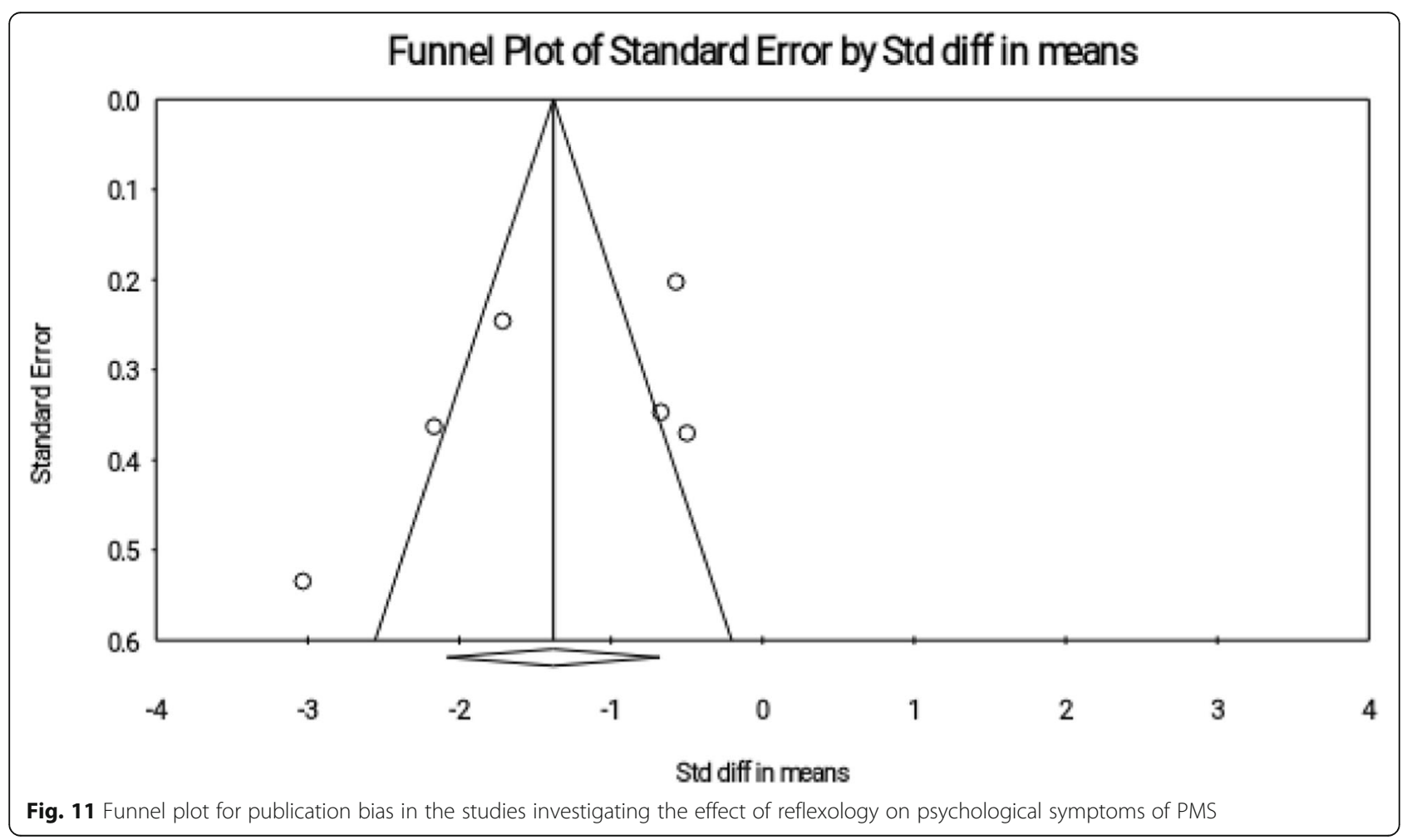




\begin{tabular}{|c|c|c|c|c|c|c|c|c|c|c|c|c|}
\hline \multirow[t]{2}{*}{ Study name } & \multicolumn{7}{|c|}{ Statistics with study removed } & \multirow{2}{*}{\multicolumn{5}{|c|}{$\begin{array}{l}\text { Std diff in means ( } 95 \% \\
\text { Cl) with study removed }\end{array}$}} \\
\hline & Point & $\begin{array}{l}\text { Standard } \\
\text { error }\end{array}$ & Variance & $\begin{array}{c}\text { Lower } \\
\text { limit }\end{array}$ & $\begin{array}{l}\text { Upper } \\
\text { limit }\end{array}$ & Z-Value & p-Value & & & & & \\
\hline Olesan (1998) & -1.531 & 0.421 & 0177 & -2355 & -0.706 & -3639 & 0.000 & & & & & \\
\hline $\mathrm{Km}(2004)$ & -1.222 & 0.380 & 0.144 & -1.966 & -0.477 & -3216 & 0.001 & & & & & \\
\hline Abddlahi Fard (2013) & -1.317 & 0.430 & 0.184 & -2159 & -0.475 & -3067 & 0.002 & & & & & \\
\hline Nalini (2015) & -1.116 & 0.332 & 0110 & -1.766 & -0.465 & -3.360 & 0.001 & & & & & \\
\hline Prema $(2017)$ & -1.558 & 0.408 & 0.167 & -2358 & -0.758 & -3817 & 0.000 & & & & & \\
\hline \multirow{4}{*}{ Shafaie (2018) } & -1.566 & 0.400 & 0.160 & -2350 & -0.782 & -3.916 & 0.000 & & & & & \\
\hline & -1.380 & 0.359 & 0129 & -2082 & -0.677 & -3848 & 0.000 & & & & & | \\
\hline & & & & & & & & -10.00 & -5.00 & 0.00 & 5.00 & 10.00 \\
\hline & & & & & & & & & Favours & & avou & \\
\hline
\end{tabular}

Mata Anaysis

Fig. 12 Sensitivity analysis for studies investigating the effect of reflexology on psychological symptoms of PMS

of reflexology on psychological symptoms of PMS; however, Chandrababu et al. (2019) conducted a systematic and review and meta-analysis study and found that the reflexology could reduce the anxiety of patients undergoing cardiovascular interventions [13]. The proposed mechanism of contractual medicine regarding the effectiveness of reflexology on psychological symptoms can be due to the fact that reflexology leads to the release of $\beta$ endorphins and encephalins from the brain as endogenous opiate peptides with Euphoriant effects that promote a good sense in people [14].

The robustness of results was supported for all three outcomes, namely total score, somatic and psychological symptoms of PMS; and an estimation of robustness overall effect size was obtained by removing any study from the meta-analysis. In other words, each study alone was not able to change overall results, and the significance of overall result was not affected by the outcome of a study.

Results of the present study provided valuable evidence for nurses as health care providers. Nurses can use the research results to improve symptoms of PMS in women. On the other hand, none of studies provided any adverse effects of reflexology, thereby indicating the importance of using the reflexology as an effective and less-complicated treatment. On the other hand, health policymakers can use the reflexology as a complementary and alternative therapy in the caregiver program.

\section{Limitations}

A limitation of study was the low number of studies that directly measured and reported somatic symptoms as outcomes; Therefore, the performance of applied statistical tests was somewhat affected to examine the publication bias in the studies. Another limitation was the publication bias in studies that examined the impact of reflexology on overall score of PMS. In this regard, adjusted effect size was measured by applying the trim and fill method. Another limitation of study was the poor and incomplete report of studies in study design and participants' age. In some studies, we received more detailed information by emailing authors.

\section{Conclusion}

In general, results of the present study indicated that the reflexology could relieve symptoms of PMS, so that overall score, somatic and psychological symptoms of PMS decreased by application of a reflexology intervention. Furthermore, the increased duration of reflexology in each session increased its efficiency. In this regard, it is suggested increasing the efficiency of reflexology by increasing intervention time of each session. The reflexology, as an effective intervention, can be utilized by nurses in the caregiver program. A logical step towards the future clinical trials is to compare reflexology interventions with other complementary and alternative therapies in order to provide a systematic review and metaanalysis study in this regard.

\section{Additional file}

Additional file 1. The search strategy used in the
systematic review. (DOCX $14 \mathrm{~kb}$ )

\section{Acknowledgements}

Not applicable.

Authors' contributions

MMM, MH, HS planned and developed the idea, selected, extracted and evaluated the data, and wrote the first draft of the manuscript. MMM and HS performed the statistical analysis, evaluated the data, and contributed in writing the manuscript. All authors selected, extracted and evaluated and contributed in writing the manuscript. All authors read and approved the final manuscript.

Funding

This research did not receive any specific grant from funding agencies. 


\section{Availability of data and materials}

The datasets used during the current study are available from the corresponding author on reasonable request.

Ethics approval and consent to participate Not applicable.

\section{Consent for publication}

Not applicable.

\section{Competing interests}

The authors declare that they have no competing interests.

Received: 13 June 2019 Accepted: 4 October 2019

Published online: 24 October 2019

\section{References}

1. Jang SH, Kim DI, Choi MS. Effects and treatment methods of acupuncture and herbal medicine for premenstrual syndrome/premenstrual dysphoric disorder: systematic review. BMC Complement Altern Med. 2014;14:11.

2. Zietal BE. "The Premenstrual Syndrome"(1953), by Raymond Greene and Katharina Dalton. Embryo Project Encyclopedia. 2017.

3. A DM, K S, A D, Sattar K. Epidemiology of premenstrual syndrome (PMS)-a systematic review and meta-analysis study. Journal of clinical and diagnostic research : JCDR 2014:8(2):106-109.

4. Direkvand-Moghadam A, Sayehmiri K, Delpisheh A, Kaikhavandi S. Epidemiology of premenstrual syndrome (PMS)-a systematic review and meta-analysis study. J Clin Diagn Res. 2014;8(2):106.

5. Ramezanpour F, Bahri N, Bagheri L, Fathi Najafi T. Incidence and Severity of Premenstrual Syndrome and its relationship with Social and Demographic Characteristics among Students' College, Gonabad - 2013. The Iranian Journal of Obstetrics, Gynecology and Infertility. 2015;18(170.169):21-8.

6. Siahbazi S, Montazeri A, Taghizadeh Z, Masoomie R. The consequences of premenstrual syndrome on the quality of life from the perspective of affected women: a qualitative study. Journal of Research in Medical and Dental Science. 2018:6(2):284-92.

7. Barth C, Villringer A, Sacher J. Sex hormones affect neurotransmitters and shape the adult female brain during hormonal transition periods. Front Neurosci. 2015;9:37.

8. Nevatte T, O'Brien PM, Bäckström T, Brown C, Dennerstein L, Endicott J, Epperson CN, Eriksson E, Freeman EW, Halbreich U, Ismail K, Panay N, Pearlstein T, Rapkin A, Reid R, Rubinow D, Schmidt P, Steiner M, Studd J, Sundström-Poromaa I, Yonkers K: ConsensusGroup of the International Society for Premenstrual Disorders. ISPMD consensus on the management of premenstrual disorders. Arch Womens Ment Health. 2013;16(4):279-91.9. Magon N. Gonadotropin releasing hormone agonists: Expanding vistas. Indian journal of endocrinology and metabolism. 2011;15(4):261-7.

9. Magon N. Gonadotropin releasing hormone agonists: expanding vistas. Indian journal of endocrinology and metabolism. 2011;15(4):261-7.

10. Sostres C, Gargallo CJ, Arroyo MT, Lanas A. Adverse effects of non-steroidal anti-inflammatory drugs (NSAIDs, aspirin and coxibs) on upper gastrointestinal tract. Best Pract Res Clin Gastroenterol. 2010;24(2):121-32.

11. Abdollahi Fard S, Dolatian M, Heshmat R, Alavi MH. Effect of foot reflexology on physical and psychological symptoms of premenstrual syndrome. Pajoohande. 2013;18(1):8-15.

12. Shafaie FS, Shirazi HD, Kamalifard M, Ghojazadeh M. The effect of foot medical zone-therapy reflex on the intensity of PMS symptoms in students (double-blind random controlled clinical trial). Iranian Journal of Obstetrics, Gynecology and Infertility. 2018;21(7):10-9.

13. Chandrababu R, Rathinasamy EL, Suresh C, Ramesh J. Effectiveness of reflexology on anxiety of patients undergoing cardiovascular interventional procedures: a systematic review and meta-analysis of randomized controlled trials. J Adv Nurs. 2019:75(1):43-53.

14. Lakasing E, Lawrence D. When to use reflexology. Primary Health Care (through 2013). 2010;20(1):16-9.

15. Khorsand A, Tadayonfar MA-R, Badiee S, Aghaee MA, Azizi H, Baghani S. Evaluation of the effect of reflexology on pain control and analgesic consumption after appendectomy. J Altern Complement Med. 2015;21(12):774-80.

16. Liberati A, Altman DG, Tetzlaff J, Mulrow C, Gøtzsche PC, loannidis JPA, et al. The PRISMA statement for reporting systematic reviews and meta-analyses of studies that evaluate healthcare interventions: explanation and elaboration. BMJ. 2009:339:b2700.

17. Higgins J, Green S, Cochrane handbook for systematic reviews of interventions. Version 5.1. 0. Oxford. UK: The Cochrane Collaboration; 2011. p. 2014.

18. Oleson T, Flocco W. Randomized controlled study of premenstrual symptoms treated with ear, hand, and foot reflexology. Obstet Gynecol. 1993;82(6):906-11.

19. Kim YH, Cho SH. The effect of foot reflexology on premenstrual syndrome and dysmenorrhea in female college students. Korean J Women Health Nurs. 2002;8(2):212-21

20. Kim YS, Kim MZ, Jeong IS. The effect of self-foot reflexology on the relief of premenstrual syndrome and dysmenorrhea in high school girls. Taehan Kanho Hakhoe chi. 2004:34(5):801-8.

21. Lee Y-M. Effects of aroma-foot-reflexology on premenstrual syndrome, dysmenorrhea and lower abdominal skin temperature of nursing students. Korean J Adult Nurs. 2011;23(5):472-81.

22. Baghdassarians $A$, Bagheri Karimi A. The efficiency of reflexotherapy over $A$ and $D$ groups premenstrual syndrome symptoms relief. International Conference on behavioral science and social studies; Tehran, Iran2015.

23. Nalini R, Jacob J. Effectiveness of reflexology on premenstrual syndrome among students. International Journal of Advances in Nursing Manegment. 2015:3(2):139-44.

24. Prema S, Pushpamala R, Lamiaa Ahmed E, Ibtesam N. Effect of foot reflexology on the relief of premenstrual syndrome and dysmenorrhea. International Journal of Science and Research. 2017;6(11):2095-100.

25. Lee J, Han M, Chung Y, Kim J, Choi J. Effects of foot reflexology on fatique, sleep and pain: a systematic review and meta-analysis. J Korean Acad Nurs. 2011:41(6):821-33.

\section{Publisher's Note}

Springer Nature remains neutral with regard to jurisdictional claims in published maps and institutional affiliations.

Ready to submit your research? Choose BMC and benefit from:

- fast, convenient online submission

- thorough peer review by experienced researchers in your field

- rapid publication on acceptance

- support for research data, including large and complex data types

- gold Open Access which fosters wider collaboration and increased citations

- maximum visibility for your research: over $100 \mathrm{M}$ website views per year

At BMC, research is always in progress.

Learn more biomedcentral.com/submission 